\title{
Morphology of the adult and immatures of a striking new species of leaf-mining Brachys Dejean from Brazil (Buprestidae, Agrilinae)
}

\author{
Letizia Janaina Migliore ${ }^{1,3}$; Sônia A. Casari ${ }^{1,4}$ \& Gabriel Paiola ${ }^{2,5}$
}

\author{
${ }^{1}$ Universidade de São Paulo (USP), Museu de Zoologia (MZUSP). São Paulo, SP, Brasil. \\ ${ }^{2}$ Universidade Estadual Paulista (UNESP), Faculdade de Engenharia (FEIS), Departamento de Proteção Vegetal. Ilha Solteira, SP. Brasil. \\ 3 ORCID: http://orcid.org/0000-0003-2731-8185. E-mail: Imigliore@usp.br \\ 4 ORCID: http://orcid.org/0000-0003-4895-6709. E-mail: casari@usp.br \\ ${ }^{5}$ ORCID: http://orcid.org/0000-0001-9072-2338. E-mail: paiola.gabriel@gmail.com
}

\begin{abstract}
Adult and immature stages of a new species, Brachys cleidecostae sp. nov., are described and illustrated. This species represents the first leaf-mining buprestid with two broad, prominent horn-like apophyses on vertex, resembling broad horns. The material was collected within unusual shaped leaf mines in Alibertia sessilis (Vell.) K. Schum (Rubiaceae), a native species from Brazilian Savanna (Cerrado). This is the first record of Brachys associated with a host plant of family Rubiaceae.
\end{abstract}

Key-Words. Aedeagus; Brachyina; Larva; Marmelinho; Mine; Pupa.

\section{INTRODUCTION}

The subfamily Agrilinae comprises nearly a half of all known Buprestidae species and is composed of four tribes and 23 subtribes (Bellamy, $2008,2013)$. The larval stages comprise exclusively endophyte species, with three major feeding habits: xylophagous in the majority of members of the tribes Agrilini Laporte, 1835 and Coraebini Bedel, 1821; stem-miners in members of tribe Aphanisiticini Jaquelin du Val, 1863; and leaf-miners in members of tribe Tracheini Gory \& Laporte, 1835 (Bellamy, 2008; Migliore et al., 2020). The tribe Tracheini comprises four subtribes with 12 genera and represents one of the most specialized groups within Buprestidae. Within Tracheini, the subtribe Brachyina Cobos, 1979 currently includes three genera (c.f., Migliore et al., 2020): Brachys Dejean, 1833, a considerably speciose genus (140 species; Nearctic and Neotropical regions) with species adapted to live in dicotyledon plants (Waddell \& Mousseau, 1996), Taphrocerus Solier, 1833 (173 species; Afrotropical, Nearctic, Neotropical and Patagonian regions) adapted to live in monocotyledons (Story et al., 1979; MacRae, 2004), and Lius Deyrolle, 1864 (126 species; Neotropical region), probably adapted to live in dicotyledons (Lourenço et al., 2017).

In the Neotropical region, the taxonomy of Brachys species needs a critical review. Species of leaf-mining genera, including Brachys, probably due to their small size, are many times collected together with other insects (especially with Malaise trap) and forgotten with the residual material housed in the collections. Only after combing these samples it is possible to find unidentified and/or undescribed species. The Brazilian fauna of Brachys is extremely rich, counting more than 70 species described in the past (Bellamy, 2008), however studies and knowledge on this genus have practically stagnated almost half a century ago.

Representatives of genus Brachys are associated with a series of different plants families as Hamamelidaceae, Sapindaceae, Salicaceae and Tiliaceae (Weiss \& Nicolay, 1919; Nicolay \& Weiss, 1923), also with records of associations with Gramineae (Obenberger, 1937) and perennial terrestrial vine Epigaea repens L., Ericaceae (Hespenheide \& Eiseman, 2016). In the USA, 12 Brachys species live on Fagaceae, often on oaks (Hespenheide \& Eiseman, 2016). A list with part of know host plants was presented by Kogan (1964a).

Except for few species of Costa Rica and Panama (Fisher, 1922; Nicolay \& Weiss, 1923; Hering, 1942), the life-history of Neotropical Brachys, their immatures and host plant associations remain unknown. For Brazilian Brachys species, the only known immature stage and host-plant association is with Inga sessilis Mart, 1837 (Kogan, 1964a). The association with plants 
of genus Inga and Brachys has already been reported for Brachys gregori Obenberger, 1937 from Costa Rica (Hering, 1942).

Comparing with the xylophagous species (Benoit, 1996; Bílý \& Volkovitsh, 2007), leafminer buprestid larvae morphology remain almost unknown. The larvae of the Tracheini species are poorly known, and the few descriptions are focused mainly in palearctic genera of the subtribe Tracheina, such as Trachys Fabricius, 1801 and Habroloma Thomson, 1864 (Bílý, 1992). This situation is even more critical concerning to Neotropical genera, the only descriptions of larvae of Brazilian leaf-mining Buprestidae are concentrated in the years 1963 and 1964 presented by Marcos Kogan, a researcher at the Instituto Osvaldo Cruz in Rio de Janeiro. In this period, the author contributed with important biological and taxonomic aspects of leaf-mining buprestids of the genus Pachyschelus Solier, 1833 (subtribe Pachyschelina) and Leiopleura Deyrolle, 1864 (subtribe Leiopleurina), including immature forms: Kogan (1963) described the eggs, larvae, pre-pupae and pupae of three species of genus Pachyschelus: P. subundulatus Kerremans, 1896, P. fulgidipennis Lucas, 1858 and P. binderi Obenberger, 1925. Later on, Kogan (1964b) described immature forms and presented biological data for P. mimus Obenberger, 1925 and $P$. urvillae Kogan, 1964b, and a redescription of Leiopleura venustula (Gory, 1841), including immature stages and ethology (Kogan, 1964c).

In the same period Kogan (1964a) described for the first-time, ethological aspects of a new species of Brachys from Brazil, Brachys inga, including the descriptions of the adult and immature stages as egg, larva and pupa, as well as the mine. So far, this is the only description of immatures and mine of a Brazilian Brachys species.

Except for the aforementioned species and Taphrocerus elongatus (Gory, 1841), a large part of knowledge about immatures of subtribe Brachyina is limited to the Nearctic region: Brachys aerosus Melsheimer, 1845, B. ovatus (Weber, 1801), B. tesselatus (Fabricius, 1801), Taphrocerus elongatus (Gory, 1841) and T. schaefferi Nicolay \& Weiss, 1920. Regarding Taphrocerus elongates, from Argentina, Bruch (1916) reported the metamorphosis and described their egg, larva and pupa. Immatures of T. schaefferi were described by Story et al. (1979) based on material from North America. Regarding to Brachys species, Weiss \& Nicolay (1919) briefly described the larvae and pupae of B. aerosus and B. ovatus from New Jersey, USA. The larva of the latter was also partially illustrated by Böving \& Craighead (1953).

Later, Turnbow Jr. \& Franklin (1981) presented important bionomics data on Brachys tessellatus from USA and briefly characterized their larva. Recently, Hespenheide \& Eiseman (2016) described a new species of Brachys, recording an unusual host plant, and also gave important information about their development and early stages, but not described the immatures.

Following Böving \& Craighead (1953) "key to families and subfamilies", the leaf-mining larvae were characterized as having prothorax only slightly broader or even slightly narrower than the first abdominal segments or wedge-shaped, and anal opening transverse.

The new species described herein, Brachys cleidecostae sp. nov., differs from all known congeners especially by adult having two broad horn-like apophyses on vertex, feature reported for the first time for the genus, and the mine shape, which differs from the known mines of Brachys species for showing a defined orientation of larval excavation, resulting in a regular rounded shape. The host plant Alibertia sessilis (Vell.) K. Schum, a native plant of the Brazilian Cerrado, represents the first association of a Brachys species with a plant of family Rubiaceae.

\section{MATERIAL AND METHODS}

The acronyms of institutions cited along the text are given below:

MZSP: Museu de Zoologia da Universidade de São Paulo, São Paulo, Brazil;

UNESP: Universidade Estadual Paulista Júlio de Mesquita Filho, Ilha Solteira, Brazil.

The holotype adult is dried and pinned, and larva and pupa are preserved in $70^{\circ} \mathrm{GL} \mathrm{EtOH}$.

Dissection of genitalia and mouthparts of larva, followed the usual protocol, after immersion in $10 \% \mathrm{KOH}$ solution for softening the tissues and hydration of musculature, enabling the detachment of appendices and sclerites. Dissected parts were mounted in temporary slides with glycerin for observation. Illustrations were produced via camera lucida attached to microscope and subsequently edited in Adobe Photoshop, or Adobe Illustrator.

Photographs were taken with a Canon EOS Rebel T3i camera, equipped with a Canon MP-E 65 mm macro lens, attached to a StackShot macro-rail. Multi-focal images were processed with Zerene Stacker version 1.04 and edited in Adobe Photoshop CS6.

The terminologies for immatures and adult descriptions follow Costa et al. (1988) and Hespenheide (2007), respectively.

\section{Field information and host plant}

The specimens were collected during a field expedition at the "Fazenda Bovinos, Universidade Estadual de São Paulo (UNESP) (Campus Ilha Solteira)" located at Selvíria, municipality of Mato Grosso do Sul, Brazil.

The area is composed of Cerrado, a biome continuously threatened by modern agriculture production of soya, maize and rice, and pasture for livestock. In the Bovinos farm, the Cerrado vegetation has been initially removed for grazing, but several species of natural vegetation have sprouted. The predominant climate in the Cerrado is the Seasonal Tropical, with a very strong dry season during the winter (Ratter et al., 1997).

The host plant of Brachys cleidecostae sp. nov., Alibertia sessilis (Vell.) K. Schum (Rubiaceae), is a na- 
tive Cerrado species, known as "marmelinho", "marmelo-do-cerrado" or "marmelada-de-cachorro". It is a low canopy branched shrub widely distributed in Brazil (Teixeira et al., 2016).

\section{RESULTS}

\section{Morphology}

\section{Brachys cleidecostae sp. nov.}

(Figs. 1A-B, 2)

Type material: HOLOTYPE ơ (MZSP): BRAZIL. Mato Grosso do Sul: Selvíria, Fazenda UNESP Bovinos $20^{\circ} 22^{\prime} 42^{\prime \prime} \mathrm{S}, 5^{\circ}{ }^{\circ} 24^{\prime} 47^{\prime \prime} \mathrm{W}, \mathrm{XI} .2018$, in Alibertia sessilis (Vell.) K. Schum, G. Paiola leg.

Other material examined (immatures): BRAZIL. Mato Grosso do Sul: Selvíria, Fazenda UNESP Bovinos $20^{\circ} 22^{\prime} 42^{\prime \prime} \mathrm{S}, 51^{\circ} 24^{\prime} 47^{\prime \prime} \mathrm{W}$. XII.2018, G. Paiola leg. (2 larvae, 1 pupa, and 5 mines, MZSP).
Diagnosis: Body relatively small and broad, fusiform. Head with two prominent broad horn-like apophyses that extend from the vertex. Vertex and the two apophyses golden, covered with ferruginous setae. Pronotum and elytra dark brown with areas with white, yellow and brown pubescence forming distinct patches. Ventral side black, sparsely covered with white setae, except vertex. Brachys cleidecostae sp. nov. is unique in the Neotropical fauna for presenting a pair of wide horn-like apophyses on vertex.

Description of holotype (Figs. 1A-B): Measurements: total length: $3.1 \mathrm{~mm}$; elytral width at middle: $1.5 \mathrm{~mm}$. Length of apophyses on vertex: $0.3 \mathrm{~mm}$.

Head narrower than anterior margin of pronotum. Vertex golden, coarsely punctate and covered by long and thick ferruginous setae; vertex with two prominent broad horn-like apophyses, with slightly acuminate apices. Apophyses golden, coriaceous with few yellow long setae dorsally; anterior margins slightly acuminated, latero-external margins slightly convergent; ventrally, vertex apophyses densely punctate with sparse setae

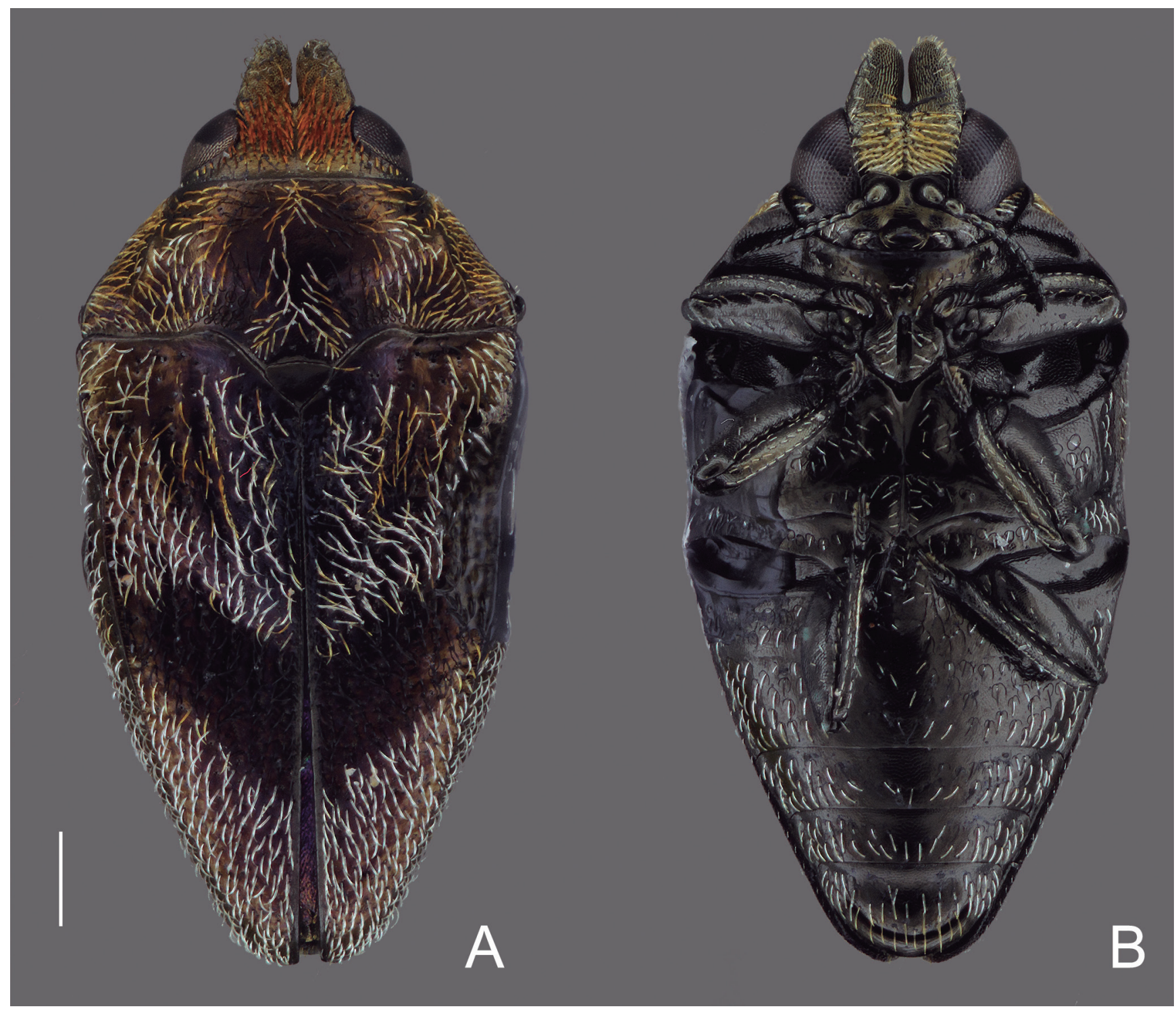

Figure 1. Brachys cleidecostae sp. nov. Holotype (male), habitus: (A) dorsal; (B) ventral. Scale bar: $=0.5 \mathrm{~mm}$. 
laterally. Frons metallic golden, dorsally with ferruginous, long, dense and thick setae, yellowish and sparser at base and around eyes; ventrally with yellowish, long and stout setae, directed from midline to lateral. Eyes very large, reniform, with posterior margin slightly concave; one pore at inner and one at outer margin of each eye. Genae short, mostly concealed into prothorax, with antennal grooves. Antennae dark brown with golden reflections and a few setae; antennomeres I-II globular, III-V cylindrical, VI-X slightly serrate. Clypeus black with golden reflections, sparsely covered with white setae laterally, markedly differentiated and raised in relation to the frons, with anterior margin sinuous. One pair of epistomal pores above the fronto-clipeal suture. Labrum convex with two long white setae each side. Pronotum dark brown, finely punctate covered with long, sparse and thick yellow setae, except two longitudinal, irregular, sinuous bands with dark-brown setae at disc, one irregular patch with white and yellow setae basal median and one each side of discal area; pronotum transverse,

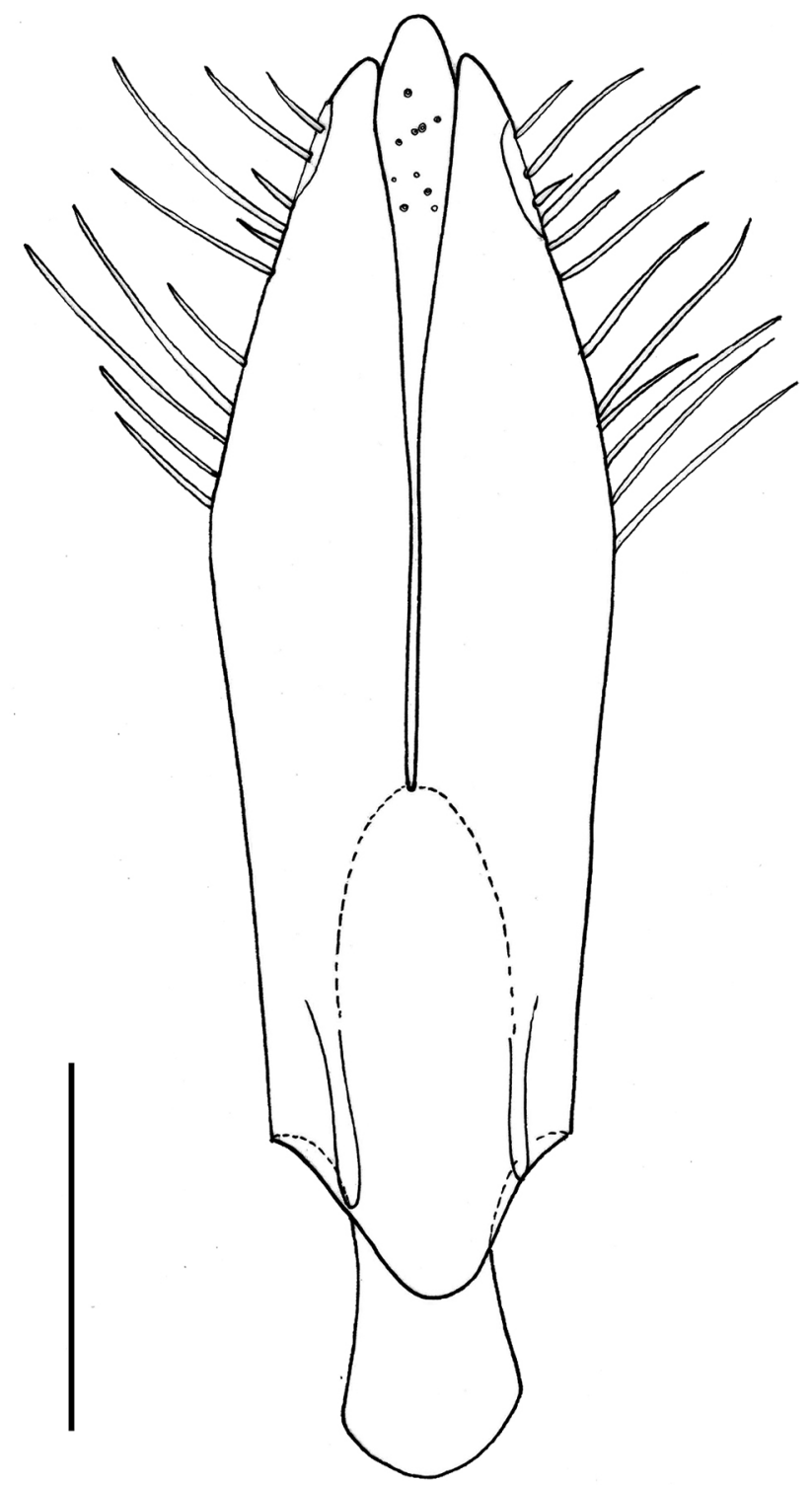

Figure 2. Brachys cleidecostae sp. nov. Aedeagus (dorsal). Scale bar: $=0.5 \mathrm{~mm}$. trapezoidal (length: $1.1 \mathrm{~mm}$, width: $0.75 \mathrm{~mm}$ ), anteriorly slightly wider than head, lateral margins slightly sinuous, wider basad; anterior margin nearly straight, pronotal disc convex anteriorly, forming declivous lateral slopes; posterior margin sinuous, very prominent and truncate at median third. Pre-marginal carina incomplete, only marked in median region. Prosternum short and broad, bordered by a row of white setae, prosternal process cordiform, sparsely covered with long and fine white setae, with longitudinal medial furrow. Hypomeron slightly coriaceous, with large and deep antennal groove. Scutellum triangular, flat, smooth and glabrous. Elytra (length: $2.2 \mathrm{~mm}$, width: $1.2 \mathrm{~mm}$ ) dark brown, with dark bronze reflections; densely covered with thick, long and moderately dense white setae, except for one inclined band on each elytron, with black pubescence forming a V-shaped band, and one irregular, elongate patch with yellow setae medioanteriorly on each elytron. Elytra sparsely punctate, slightly narrowed apicad; lateral margins wider and slightly sinuous on basal $2 / 3$, tapering posteriorly; elytra wider at meso- and metacoxal cavities level; post-humeral carina well defined, extending almost along whole elytral length; apices conjointly rounded. Epipleura visible only at metacoxal level, continuing under pleural border of abdomen. Meso- and metaventrite black, sparsely pubescent posteriorly; each seta inserted in stout, weak, irregularly rounded punctures. Legs black with dark bronze reflections, sparsely covered with white setae; tibiae slightly arcuate, with setae disposed in regular rows. Abdomen ventrally black, sparsely covered with white setae, mostly concentrated laterally; setae inserted in very stout and weak irregular rounded punctures. Ventrite $\mathrm{V}$ almost triangular, with apex widely rounded; apex deep and narrowly grooved parallel distal margin.

Aedeagus (Fig. 2): (length: $0.4 \mathrm{~mm}$, width: $0.1 \mathrm{~mm}$ ). Parameres strongly sclerotized, except for a small membranous lateral stripe near apex; each paramere with a series of varied sizes lateral setae, on distal half. Median lobe membranous, slightly tapering apicad and abruptly narrowed at apex; apex acuminate, surpassing parameres apices.

Etymology: Named in honor of Dr. Cleide Costa, a noted Coleoptera larvae researcher.

Distribution: Brazil (Mato Grosso do Sul state).

Description of mature larva (Figs. 3A-B, 4A-J): Body elongate (length: $6 \mathrm{~mm}$ ) and strongly flattened dorso-ventrally; head narrow, metathorax widest segment; body narrowed from metathorax to abdominal apex. Surface whitish, except for head and median region of thorax and part of abdomen. General integument microspined and with sparse long setae, especially laterally on thorax and abdomen (Figs. 3A-B).

Head (Figs. 3, 4A-B) prognathous, deeply retracted into prothorax and strongly flattened dorso-ventrally; yellowish, clearer posteriorly, with brown mouth frame at epistomal area, and brownish in a small lateral sclerite 
below each stemma, and dorsal and ventral small support sclerites (apodeme of the tentorial arms); elongate, narrower anteriorly and gradually widened basad; lateral margins curved; posterior margin deeply emarginate at middle forming one rounded lobe on each side; exposed area narrower than anterior margin of prothorax; two long setae below each antenna and three very short setae below each stemma; dorsally, two pairs of moderately long setae below frontoclipeal suture, and ventrally, one short pair of setae near middle of each half of head capsule, at antennal base level. Epicranial stem absent; frontal arms U-shaped. Internal dorsal support structures (apodeme of the tentorial arms) forming an open rectangle inside frontal arms, continuing in two branches each side, almost reaching head base; internal ventral support structures formed by two branches, almost reaching base. One stemma on each side, on a darker area below each antenna. Antennae (Fig. 4C) partially sclerotized, with two elongate antennomeres: basal with one dorsal campaniform sensillum latero-externally; distal with one very long and stout latero-dorsal seta near apex and, at apex one elongate and conical latero-external membranous sensorial appendix and three short sensoria near internal margin. Frontoclypeal suture (Fig. 4D) present; epistomal region heavily sclerotized. Labrum (Fig. 4D) transverse, band-like, with fore angles widely rounded; one pair of long setae on each side. Epipharynx (Fig. 4E) densely covered by stout setae, directed medially. Mandibles (Figs. 4F-G) symmetrical, broad, inner surface concave with three rounded teeth; apical tooth bilobed; one stout latero-basal long seta; penicillus long, formed by stout, ramified long setae and simple short setae near base. Maxillae (Fig. 4H): cardo well developed with one long seta; stipes short, with one long and one short seta and one campaniform sensillum; mala elongate, almost as long as palpus, with one campaniform sensillum near base; apex of mala rounded bearing three stout and long setae; palpi with two short palpomeres: basal with one latero-external long and stout seta near apex, and ventrally, one short seta and one campaniform sensillum

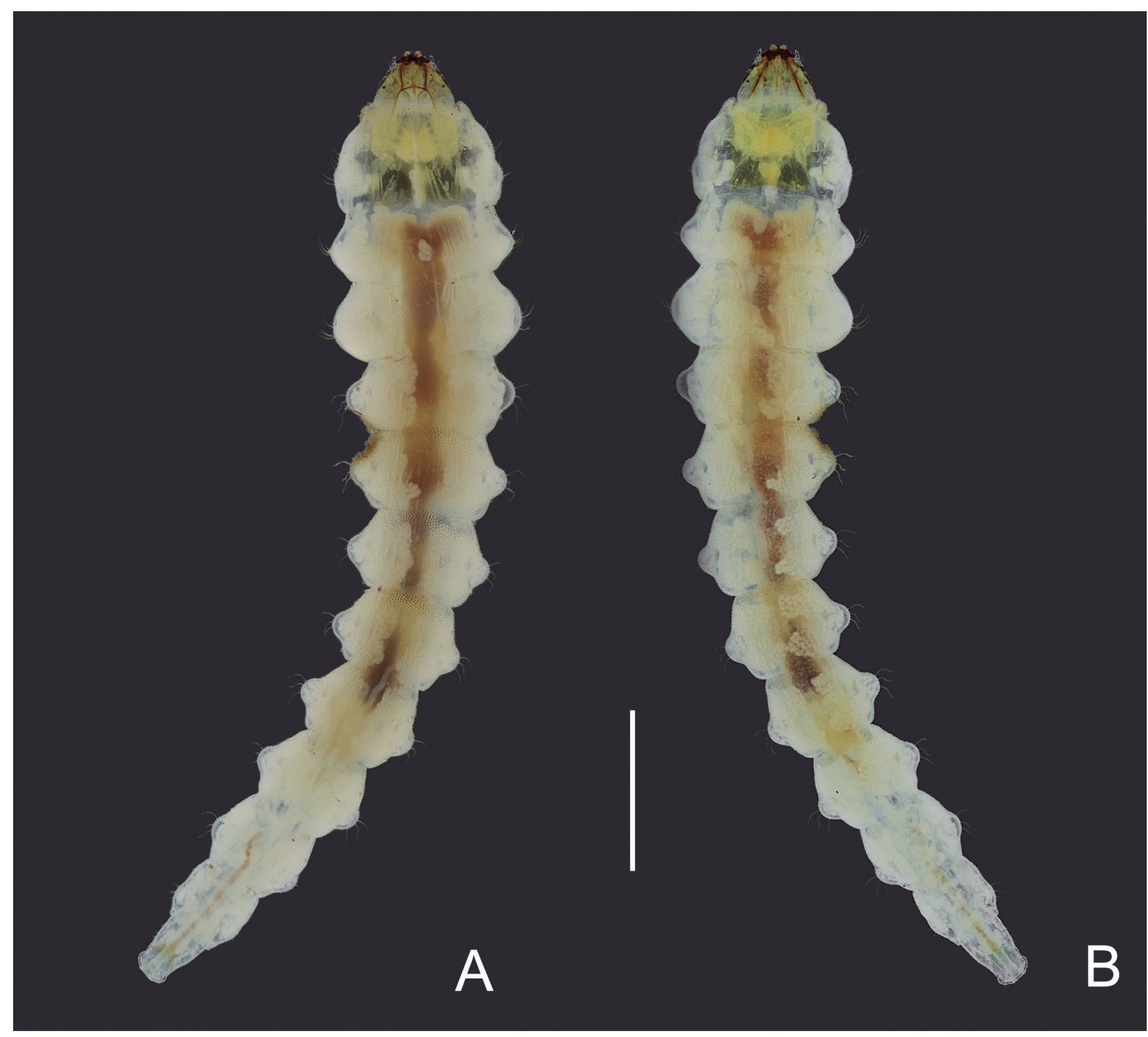

Figure 3. Brachys cleidecostae sp. nov. Mature larva, habitus: (A) dorsal; (B) ventral. Scale bar: $=1 \mathrm{~mm}$. 
near middle; distal with one latero-external campaniform sensillum and four short membranous sensilla at apex. Labium (Fig. 4H) with mentum, submentum and ligula fused into single rectangular plate, with fore angles rounded; one lateral short seta on each side, near middle. Hypopharynx (Fig. 4I) densely setose; setae directed medially; hypostomal rods long and subparallel.
Prothorax slightly wider than long, gradually widened posteriorly; lateral margins sinuous forming three lobes: one anterior, smaller and with one or two setae, and one median and one posterior almost of same size, with several setae; one dorsal and one ventral sclerotized yellow median band, reaching more than $2 / 3$ of prothorax width dorsally, divided at middle. Mesothorax slightly narrower

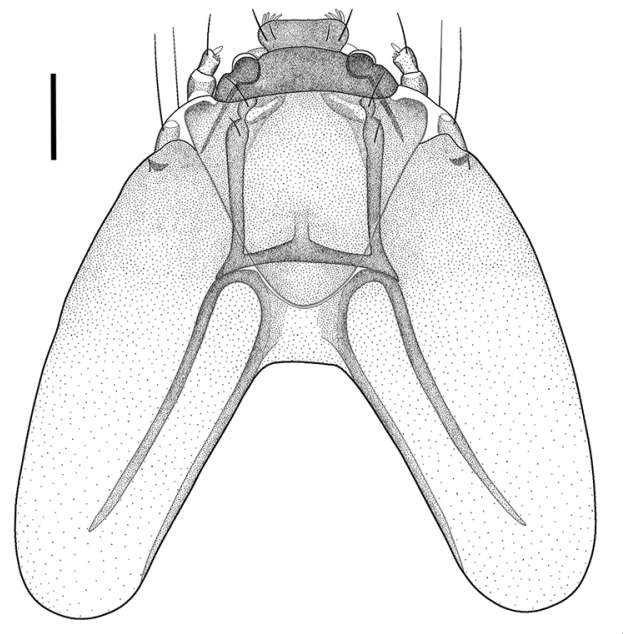

A

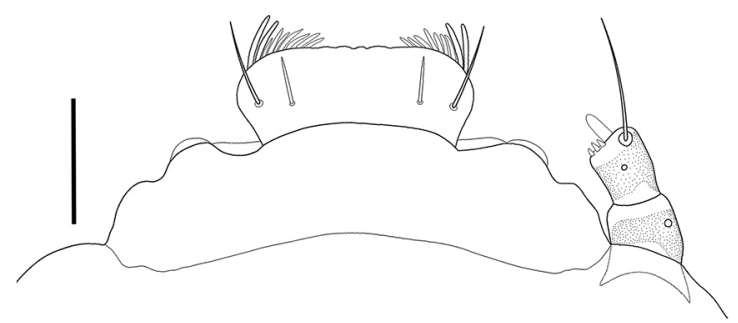

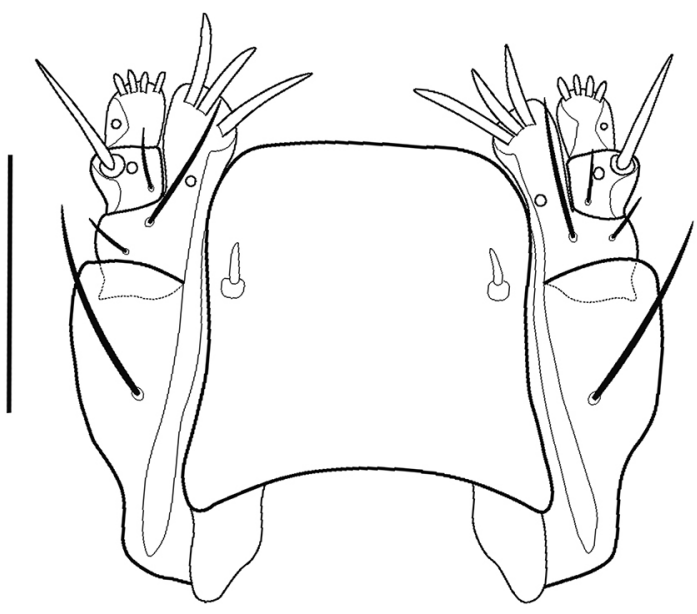

$\mathrm{H}$

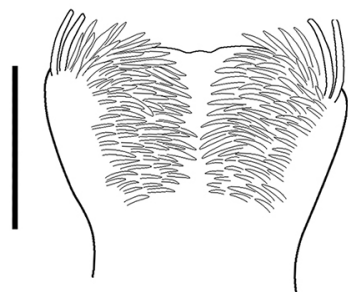

$E$

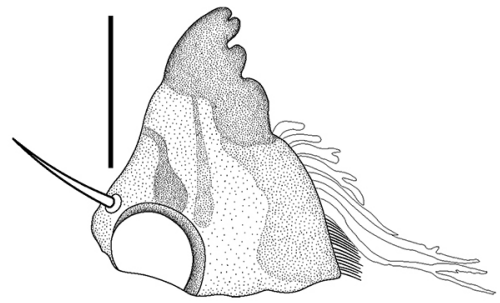

F
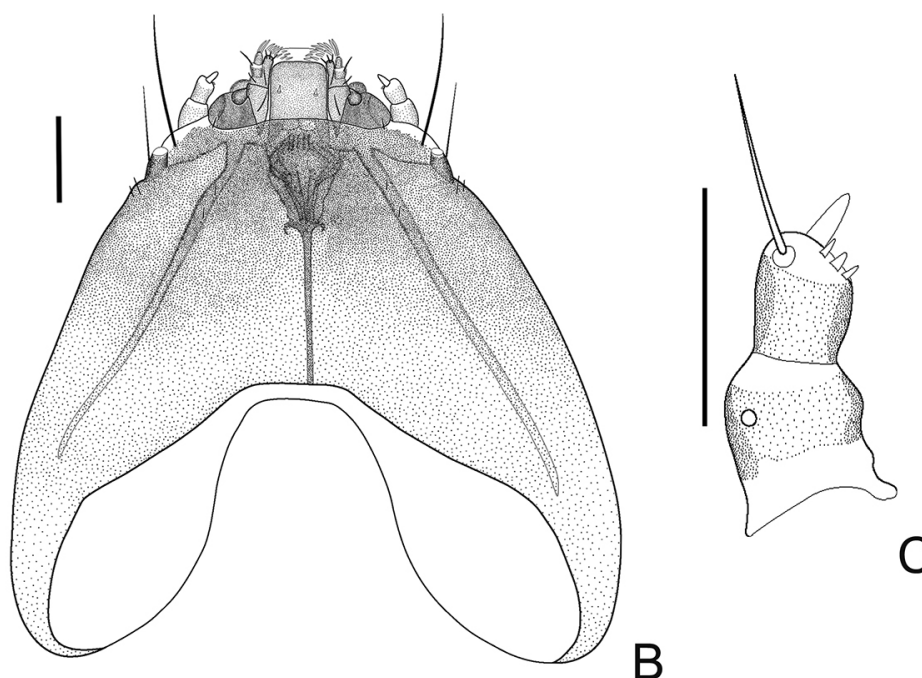

B

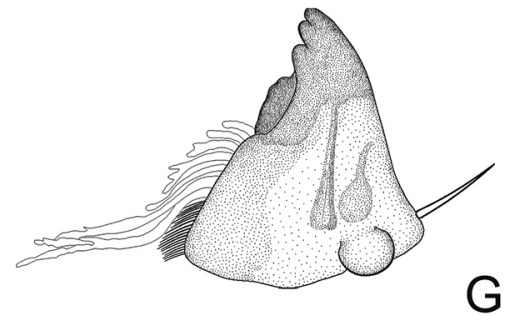

G

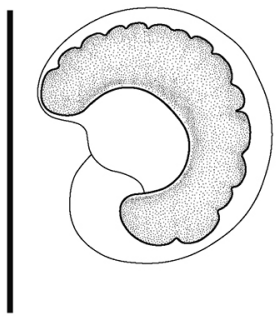

$J$

Figure 4. Brachys cleidecostae sp. nov. Mature larva: (A-B) Head (dorsal, ventral); (C) Antenna (dorsal); (D) Labrum, clypeum and antenna; (E) Epipharynx; (F-G) Mandible (dorsal, ventral); (H) Labium and maxillae; (I) Hypopharynx; (J) Thoracic spiracle. Scale bars: (A-C) = $1 \mathrm{~mm}$; (D-J) =0.5 mm. 
and of same shape as metathorax, with lateral margins strongly rounded, forming one lobe each side with four setae; a ventral and a dorsal longitudinal median sclerotized band, narrower than $1 / 3$ of width; mesonotum with anterior median $2 / 3$ with transverse irregular small carina giving a rugose appearance. Metathorax widest segment, lateral margins rounded with four setae each side; metanotum with anterior median $2 / 3$ with larger microtrichiae and two small rounded areas with rugose appearance. Mesothorax with a lateral anterior spiracle each side; spiracle (Fig. 4J) semicircular, heavily sclerotized.

Abdominal segments I-VIII decreasing in width, with one rounded lobe on each side, each lobe with three setae, decreasing in size posteriorly; each side of segments I-VIII with one lateral spiracle (smaller than thoracic), in front of lateral lobe; segments I-V with longitudinal median dorsal and ventral slightly sclerotized narrow band, decreasing in size and intensity to apex direction; median anterior area of segments I-V with dorsal and ventral larger and brown asperites; segment IX elongate with three setae on each side and a dorsal median weakly sclerotized plate; segment $\mathrm{X}$ narrow and apical, slightly wider than segment IX apex, marginate by short setae. Anal opening transverse.

Pupa description (Figs. 5A-B): Length: $3.1 \mathrm{~mm}$. Coloration, after fixation, yellow with ventral appendices bordered in brown. Integument with irregular tiny brownish patches. Glabrous.

Head band-like, trapezoidal with fore angles strongly rounded. Anterior margin very prominent forming two median elongate horn-like apophyses, almost as long as head and with rounded apex. Mouthparts hypognathous; antennae with apices fitted below profemura; labrum trapezoidal, prominent medio-anteriorly.

Pronotum trapezoidal, more than twice wider than long; anteriorly as wide as basal margin of head, strongly widened posteriorly; hind angles wide and rounded; posterior margin roundly prominent at middle. Prosternum slightly wider than long, wider basad; prosternal process almost rectangular, slightly and gradually narrowed apicad; posterior margin prominent at middle. Mesonotum band-like with posterior margin sinuous and prominent at middle; pterotheca forming rounded

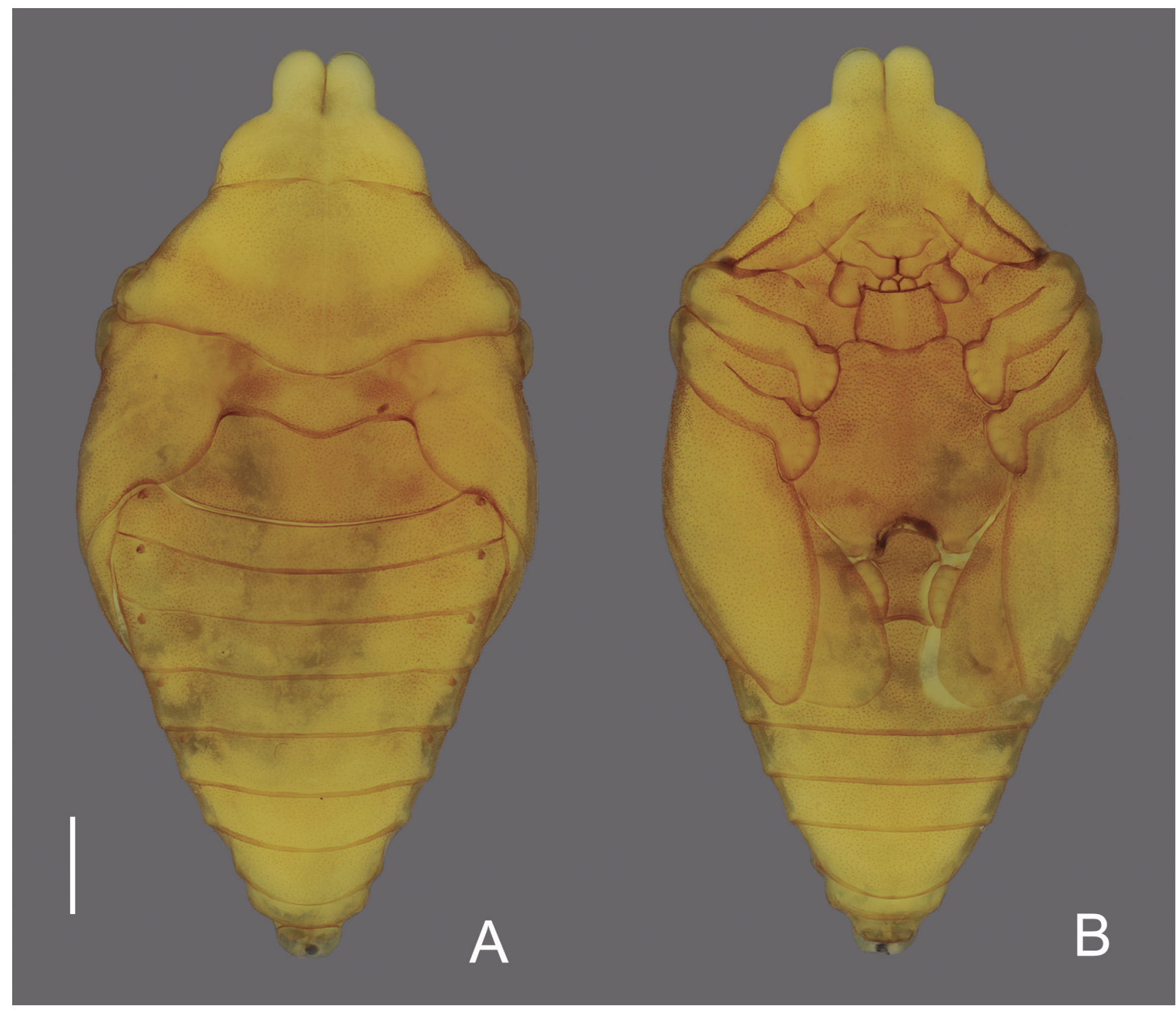

Figure 5. Brachys cleidecostae sp. nov. Pupa, habitus: (A) dorsal; (B) ventral. Scale bar: $=0,5 \mathrm{~mm}$. 
projection on metanotum. Metanotum almost twice mesonotum length, with posterior margin widely rounded. Mesosternum broad with areas to fit pro- and mesothoracic tarsi; posterior margin deeply and roundly emarginated at middle. Metasternum narrow and short; metatarsi fitted laterally. Pterothecae ventrally almost reaching apex of first ventrite.
Abdomen gradually narrowed posteriad, with nine visible tergites and seven ventrites. Tergites I-VII bandlike, narrowed apicad; tergites I-VI with one lateral spiracle on each side, at apex of short cylindrical projection, decreasing in size apicad; tergite VIII shortest; tergite IX narrowest with lateral margins rounded. Ventrites I-II fused, suture visible only in a narrow lateral area, both
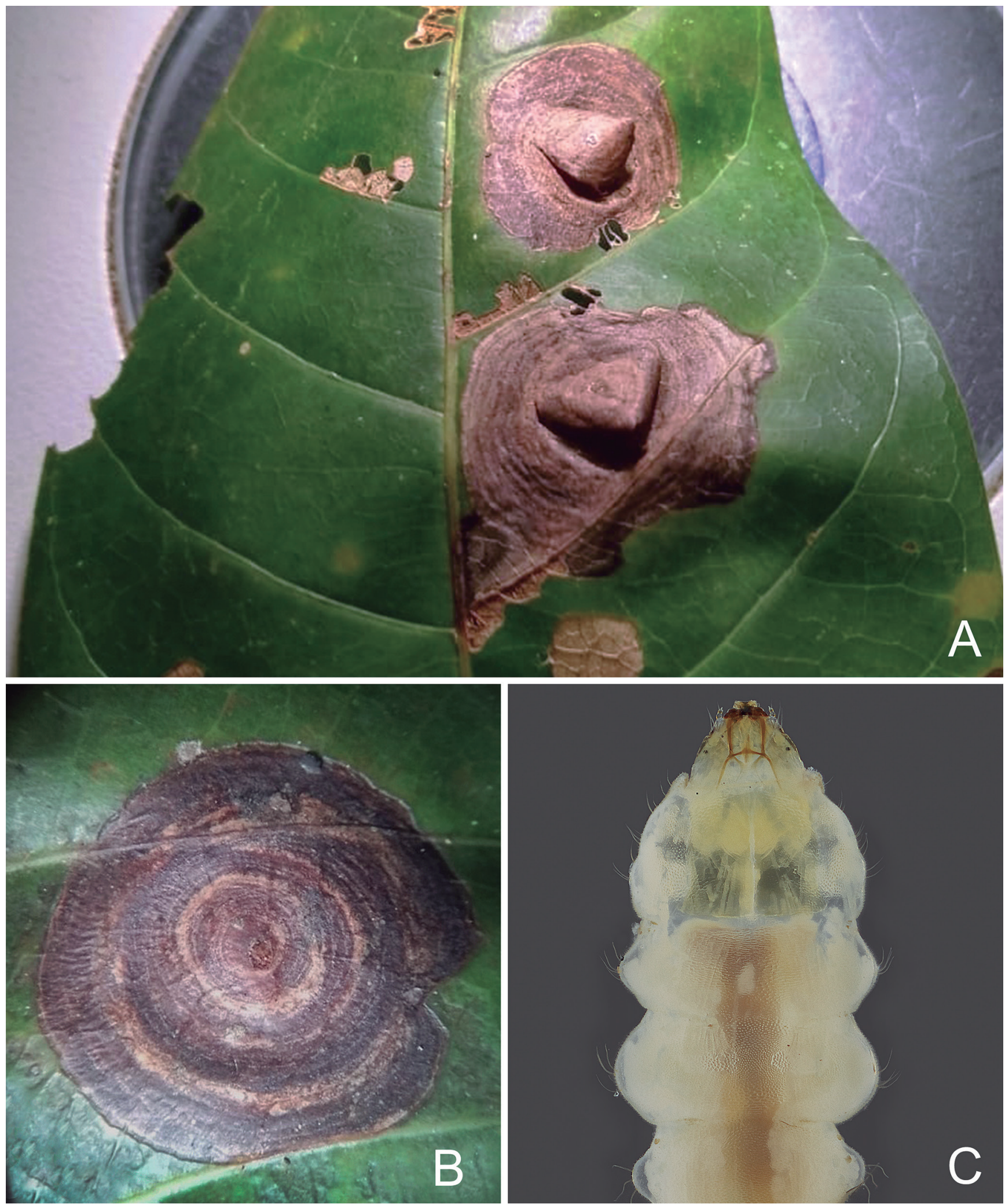

Figure 6. Brachys cleidecostae sp. nov. Mine and mature larva: (A) Leaf with two mines after opening and removal of larva and pupa; (B) Leaf with mine with pupa inside; (C) Mature larva dorsal (head and thorax). 
more than twice longer than III; III-IV band-like, almost same length; ventrite $\mathrm{V}$ longer and narrower than previous, gradually narrowed posteriorly with posterior margin widely rounded; ventrite VI band-like, shorter than remainders; ventrite VII narrower and trapezoidal, almost as long as $\mathrm{VI}$.

\section{Biology of Brachys cleidecostae sp. nov.}

In December 2018, one to five mines of B. cleidecostae sp. nov. (Figs. 6A-B) were observed on each leaf, separated by the main leaf veins. However, most of the mines were already unoccupied, indicating that the adults had already emerged and flown away, or did not complete their entire cycle, probably due to various factors as predation or parasitism. Inside mines were collected one last instar larva, an early instar larva and one adult; the pupa was collected inside the pupal chamber.

Based on the marks found in leaves and mines, we concluded that the eggs are deposited isolated on upper surface of the leaf, in the middle of a leaf blade, maintaining an equivalent distance from the midrib and from the leaf edge. The eggshell is preserved and visible after hatching, even after larval complete development. It is probable that the first-instar larva hatches and starts mining on a circular trail. The trail forms a spiral from the peripheral leaf area towards the center, where the pupal chamber is built. The pupal chamber is circular and silky. External coloration of the mine appears brown and opaque.

\section{DISCUSSION}

Adult morphology: Brachys cleidecostae sp. nov. differs from all congeners by the stout horn-like projecting apophyses on vertex. This feature is distinctive and is not found in any described species of the tribe Tracheini, providing reliable diagnostic characters for this species. A similar feature is found only in few species of Chrysobothris Eschscholtz, 1829 (Buprestinae, Chrysobothrini), and in some undescribed species of oriental Trachys (Gigli Maurizio, personal communication), but the structures are narrower and look very different. Wherever, in the known species of genus Chrysobothris, only males have this feature, as a sexual dimorphism. Brachys cleidecostae sp. nov. is known only from one male, and we could not assure whether the horn-like apophyses represent sexual dimorphism.

The genus Brachys is rich in species, with their representatives showing great variations in size and color. The genus is known to contain the largest species among the leaf-mining Buprestidae (Cobos, 1979); B. cleidecostae sp. nov. differs considerably from the genus type-species Brachys tesselatus and from numerous other species by their much smaller size $(3.1 \mathrm{~mm})$. Regarding the coloration and pubescence, $B$. cleidecostae sp. nov. is very similar to some undescribed species of Brachys from Brazilian fauna. However, as already discussed by some authors (Kogan, 1964a; Nicolay \& Weiss, 1923) these characteristics are uninformative to differentiate species in comparison to characters of genitalia.

In general, females show greater morphological variation than males, especially in the last ventrite (Nicolay $\&$ Weiss, 1923), however, in the absence of females of $B$. cleidecostae sp. nov. it is not possible to make a comparison. The aedeagi of known males of Brachys are similar and quite characteristic, having the parameres strongly sclerotized, except by membranous lateral stripe near apex where a series of sensory setae are usually located and the differences are mostly in the forms. Comparing the aedeagus of $B$. cleidecostae sp. nov. with illustrations of the aedeagus of $B$. inga, it was observed a difference in the width of the parameres and in the membranous area, which is absent in $B$. inga. In B. cleidecostae sp. nov., the aedeagus is conspicuously narrowed towards the apex while that of $B$. inga presents a more gradual constriction.

Immatures morphology: Larvae of Brachys cleidecostae sp. nov. are characterized especially by having body gradually narrowed from metathorax to apex of abdomen, and one lateral lobe each side on abdominal segments I-VIII, each with three setae; distal antennomere, apically with one elongate and conical latero-external membranous sensorial appendix and three short sensoria near internal margin; labrum with two pairs of setae; mandibles with three rounded teeth (apical tooth bilobed) and penicillus long, formed by simple and ramified setae; mala of maxillae with three stout setae.

Comparing the known larvae of Brachys species, it was verified that they are whitish with head and mouthparts dark; integument miscrospined; well-developed and smooth prothorax, shining subquadrate plate dorsal and ventral; prothorax (B. inga, $B$. ovatus) or metathorax (B. cleidecostae sp. nov.) widest; abdominal segments I-VII rounded laterally (B. inga, $B$. ovatus) or with pronounced lateral rounded lobes (B. cleidecostae sp. nov.), each with varied number of setae: three setae on each side in B. cleidecostae sp. nov., several in B. inga and five in B. ovatus. Head with dorsal and ventral apodemes of the tentorial arms, with one stemma on each side, antennae with two antennomeres (apical antennomere with sensorium well developed) or three antennomeres (B. inga); mandibles wide with three teeth and penicillum short with simple setae in $B$. inga, and long with simple and ramified setae in B. cleidecostae sp. nov.; and labium undifferentiated, formed by unique piece, with two long setae, and palpi lacking. Spiracles semicircular, unbranched trabeculate, present at mesothorax and abdominal segments I-VIII. It is not possible to compare other structures because descriptions or illustrations are not available.

The larvae of Taphrocerus and Leiopleura species are very similar to those of Brachys, except for the antennae with three antennomeres. Bruch (1916) and Story et al. (1979), considered respectively the antennae of T. elongatus and T. schaefferi with three antennomeres, but the $3^{\text {rd }}$ antennomere, considered by them as "diminuto", is actually the distal membranous sensorium. We suppose that the same occurred with Kogan (1964c) in Leiopleura venustula. All species have one stemma on each side, 
maxillary palpi with two palpomeres and labial palpi missing, and mandibles robust and 3-toothed, except in Taphrocerus schaefferi, 4-toothed, and in Leiopleura venustula, with two teeth.

Regarding the pupae of Brachyina species, they are glabrous with different coloration: yellow, bordered in brown in Brachys cleidecostae sp. nov.; brown ochre, smooth and shining in Brachys ovatus; shining reddish-brown in Taphrocerus elongates; initially translucent white and reddish-brown through most of development in Taphroceus schaefferi; and brownish in Brachys inga.

Mine: The usual mines of known species of Brachys consist in blotches that occupy a large part of the leaf, and the larva does not have a defined orientation towards mining, forming irregular figures in the leaf. Often the larva does not build a pupal chamber, emerging through a hole in the underside of the leaf (Weiss \& Nicolay, 1919; Kogan, 1964a; Hespenheide \& Eiseman, 2016). However, B. cleidecostae sp. nov. exhibits a different pattern of larval feeding and pupation. Once the larva achieves maturity, the mine has a spiral aspect and occupies a small part of the leaf, rarely extending beyond a leaf blade, showing that the larva has an orientation towards the excavation.

In the only other Brazilian species with known mine, $B$. inga, the larval excavation is similar to that already reported for the Nearctic Brachys species (Kogan, 1964a) making $B$. cleidecostae sp. nov. unique among its congeners. It is still unclear whether the spiraling mine can reduce environmental stresses, like sun exposure, dryness and avoiding parasitoids.

Although very little is known about the life history of the members of the genus, the available information shows a wide range of use of hosts from different plant families, from woody plants to grasses, dicotyledons and monocotyledons hosts (Kogan, 1964a). In Brazil, the genus Brachys presents a broad distribution through different biomes, comprising an extreme diversification of environments, from vast tropical forests to arid areas, like for $B$. inga and $B$. cleidocostae sp. nov., described respectively from the Atlantic Forest and Cerrado. The fauna diversification and strategies of host utilization are probably conditioned by the phytogenetic diversity and distribution of their host plant, as the species have a strong host specificity.

\section{ACKNOWLEDGMENTS}

We thank Dr. Carlos Fletchmann (UNESP Ilha Solteira) for his support during our survey in Ilha Solteira and in the UNESP's "Fazenda Bovinos" and "Fazenda Cerrado"; two anonymous reviewers for valuable suggestions on manuscript; G. Biffi (MZSP) for incentive, corrections and suggestions on manuscript. SAC expresses sincere gratitude to Dr. Cleide Costa for her teachings, supervising and incentive on studying immature beetles. This work was supported by grants to LJM from Coordenação de Aperfeiçoamento de Pessoal de Nível Superior (CAPES88882.378128/2019-01) and to GP from Fundação de Amparo à Pesquisa do Estado de São Paulo (FAPESP 2017/19841-6).

\section{REFERENCES}

Bellamy, C.L. 2008. A World Catalogue and Bibliography of the Jewel Beetles (Coleoptera: Buprestoidea). Volume 4: Agrilinae: Agrilina through Trachyini. Sofia-Moscow, Pensoft Publ. p. 1932-2684.

Bellamy, C.L. 2013. The world of Jewel beetles, Insecta:Coleoptera: Buprestidae. Version 25/08/2014. http://cerambycids.com/buprestidae/index.html. Access in: 12/2019.

Benoit, P. 1966. Descriptions of some Chrysobothris larvae (Coleoptera: Buprestidae) occurring in the United States and Mexico. The Canadian Entomologist, 98(3): 324-330.

Bílý, S. 1992. The larva of Trachys troglodytes (Coleoptera: Buprestidae) and a key to the trachyine larvae of Scandinavia. Insect Systematics \& Evolution, 23.4: 415-418.

Bílý, S. \& Volkovitsh, M.G. 2007. Descriptions of some buprestid larvae from Chile (Coleoptera: Buprestidae). Folia Heyrovskyana, Series A, 15: 53-79.

Böving, A.G. \& Craighead, F.C. 1953. An illustrated synopsis of the principal larval forms of the order Coleoptera. Entomologica Americana, 11:1-351.

Bruch, C. 1916. Metamorfosis de Taphrocerus elongatus Gory. Anales de la Sociedad Científica Argentina, 82: 251-256.

Costa, C.; Vanin S.A. \& Casari-Chen S.A. 1988. Larvas de Coleoptera do Brasil. São Paulo, Museu de Zoologia da Universidade de São Paulo. 365p.

Fisher, W.S. 1922. The leaf and twig mining buprestid beetles of Mexico and Central America. Proceedings of the United States National Museum, 62(8): 1-95.

Hering, E.M. 1942. Neotropische Buprestiden-Minen. Arbeiten über Physiologische und Angewandte Entomologie, 9(4): 241-249.

Hespenheide, H.A. 2007. A new genus and species of Buprestidae (Coleoptera) from Costa Rica. Folia Heyrovskyana, Series A, 15(1): 1-6.

Hespenheide, H.A. \& Eiseman, C.S. 2016. A New Species of Brachys Dejean, 1833 (Coleoptera: Buprestidae) from the Eastern United States Using an Unusual Host. The Coleopterists Bulletin, 70(2): 335-340. D0I

Kogan, M. 1963. Contribuição ao conhecimento da sistemática e biologia de buprestídeos minadores do gênero Pachyschelus Solier, 1833: (Coleoptera, Buprestidae). Memórias do Instituto Oswaldo Cruz, 61(3): 429-457.

Kogan, M. 1964a. Notas biológicas e descrição de uma nova espécie do gênero "Brachys" Solier, 1833, minadora de fôlhas de "Inga sessilis" (Coleoptera, Buprestidae). Revista Brasileira de Biologia, 24: 393-404.

Kogan, M. 1964b. Estudos taxionômicos e biológicos sobre buprestídeos minadores do gênero Pachyschelus Solier, 1833, com a descrição de uma espécie nova (Insecta, Coleoptera). Memórias do Instituto Oswaldo Cruz, 62: 63-76.

Kogan, M. 1964c. Observações sobre a sistemática e a etologia de um buprestídeo do gênero Leiopleura Deyrolle, 1864, minador de folhas de Jaqueria. In: Congresso Latino-Americano de Zoologia $2^{\circ}$. Anais. São Paulo, Departamento de Zoologia da Secretaria da Agricultura, 1962. v. 1, p. 197-206.

Lourenço, S.L.O.; Luiz, M.F.; Jesus F.G.; Carvalho, D.D.C.; Hornburg, M. \& Araújo, M.S. 2017. Predispersal infestation of Vochysia haenkeana seeds by Lius conicus. Ciência Rural, 47(9): 1-7. DOI

MacRae, T.C. 2004. Notes on host associations of Taphrocerus gracilis (Say) (Coleoptera: Buprestidae) and its life history in Missouri. The Coleopterists Bulletin, 58(3): 388-390. DOI

Migliore, L.J.; Biffi, G. \& Curletti, G. 2020. A revision of Cylindromorphoidina: comparative morphology, genera reassessment and description of new species (Coleoptera, Buprestidae, Agrilinae). Insect Systematics \& Evolution, [1-41]. D0I

Nicolay, A.S. \& Weiss, H.B. 1923. The group Traches in North America, Part II. The genus Brachys. Journal of the New York Entomological Society, 31(2): 59-76. 
Obenberger, J. 1937. De generis Brachys Solier speciebus novis (Col. Buprestidae). Entomologické Listy, 1: 17-28.

Ratter, J.A.; Ribeiro, J.F. \& Bridgewater, S. 1997. The Brazilian cerrado vegetation and threats to its biodiversity. Annals of Botany, 80(3): 223-230.

Story, R.N.; Robinson, W.H.; Pienkowski, R.L. \& Kok, L.T. 1979. The biology and immatures stages of Taphrocerus schaefferi, a leaf-miner of yellow nutsedge. Annals of the Entomological Society of America, 72(1): 93-98.

Teixeira, T.R.; Pádua, M.S. \& Castro, A.H.F. 2016. Leaf anatomy of Cordiera sessilis (Vell.) Kuntze (Rubiaceae). Acta Scientiarum. Biological Sciences, 38(3): 355-364
Turnbow Jr., R.H. \& Franklin, R.T. 1981. Bionomics of Brachys tessellatus in coastal plain scrub oak communities. Annals of the Entomological Society of America, 74(4): 351-358.

Waddell, K.J. \& Mousseau, T.A. 1996. Oviposition preference hierarchy of Brachys tessellatus (Coleoptera: Buprestidae). Environmental Entomology, 25: 63-67.

Weiss, H.B. \& Nicolay, A.S. 1919. Notes on the life-history and early stages of Brachys ovatus Web. and Brachys aerosus Melsh. The Canadian Entomologist, 51: 86-89. 